\title{
43 職員鼻前庭における黄色ブドウ球菌の保有状況及び除菌方法別効果について
}

片井敦雄（社会保険紀南綜合病院中央臨床険査部）, 広瀬 栄 (同薬剤部), 田中米子 (同看護部), 山沢 亨 (同小児科), 永井 勲 (同外科)

〔目的〕黄色ブドウ球菌は, 院内感染の感染源の一つ として医療従事者の舅前庭保菌が指摘され重要視され ている. 我々も当院に括汗る陸内感染予防対策の一環 として職員䁷前庭保菌調査と除壂に取り組又, 平成 2 年 12 月より, 平成 9 年 6 月迄計 12 回，延人数 5,478 名 実施している，今回これらの成績を報告する。

〔検査方法〕材料は咽頭用スワブ(シードスワブ 1 号) を用いて左右鼻前庭から別々に採取した，分離培地は エッグョーク寒天培地（栄研）を使用し，37 C 48時閌 培荃後コアグラーゼ試験で同定を行った．MRSAの 判定はオキサシリンのディスク判定 (K-B 法)により 行った。検査実施年・月 (人数) は, (1) H2.12（103） (2) H3. 4 (298) (3) H3.8 (252) (4) $\mathrm{H} 4.2$ (256) (5) H4.7 (535) (6) H4. 12 (579) (7) H5. 4 (556) (8) H5. 10 (568) (9)H6. 5 (595) (10) H7.6 (502) (11) H8.7 (602) (12) H9. 6 （603）の計12回，延人数は 5,478 名行った.

〔除菌法〕1. FOM 散布 FOM に感受性の保菌者に は，FOM の注射用製剤を $20 \mathrm{mg} / \mathrm{m} l$ の濃度に調製し 点鼻容器を用いて両鼻腔に 3 回ずつ朝夕 2 回 3 日間散
饰を1クールとし，1回目から11回目迄実施した。

2. Mupirocin 軟高 5 回目の MRSA 保菌老と, 5 回 目以降の FOM 耐性対象老は Mupirocin 軟高を使用 し，1日3回 3 日間の塗布を 1 クールとした。

3.イソジンゲル イソジンゲルを 1 日 3 回 3 日間を 1 クールとし，11回目の保菌者全員に央施した。各除菌 結果の採取時期は，FOM 散布とイソジンゲルは治療 最終後装日から 1 週間以内に 1 回, Mupirocin 軟高で は羿日上 1 週間後の 2 回（治験含）に亘って検索した。 〔結果〕籍 1 回から12回迄の陽性率 (MSSA \%: MRSA \%) は, (1) $(32.0: 14.6)$ (2) (25.2:7.4) (3) $(25.4: 4.4)$ (4) $(19.5: 4.3)$ (5) $(16.3: 3.6)$ (6) $(17.1: 2.6)$ (7) $(12.4: 2.0)$ (8) $(22.4: 2.3)$ (9) (16.5:2.4) (10) $(18.7: 1.4)$ (11) $(22.7: 2.4)$ (12) (22.4:2.4) であった. 方法別に上る鼻前庭除菌の成 績は, FOM 散布と Mupirocin 軟膏は, 1 クールで80 \%を超寸成績であったが，イソジンゲルは1クールで $24.4 \%$ あった。

\section{4 手術用手袋のインピーダンスを対象とした経時的変化 「特に直流効果を主対象として」}

加藤伸彦, 黒田 聡 (札幌医療科学専門学校), 和田龍彦 (北海道大医療技術短期大学部), 佐藤直樹（北海道大病院手術部），佐野文夫（札幌社会保険総合病院），

三浦哲夫（田島クリニック），米岡宗臣（アンセンメディカル）

手術用ゴム手袋の材質は天然ゴムラテックスが主流 を占めている．伸び率や極薄加工の点に優れた特長を 有し，外界との遮断や絶縁など，生体の保護を目的と するのだが，長時間の使用では，胿間経過に伴い丁袋 に材質的执よび構造的変化が生じて，ミクロのレベル でバリアー性に破壊をきたすとされている。このこ上 は，增加する感染症，手術の対策上きわめて重要な問 題であり，使用手袋の限界や交換時期女あらかじめ推 定することは, 医療従事者にとってきわめて重要なこ とと考觉れる。
したがって，通常使用時の手袋に対する安全な使用 時䦌の検討が急務である。

さて，電気メス使用による手袋破壊などについては， 既に本学会で報告したが，本報では，術者の身を守る 手術用手袋のインピーダンス成分が交流および直流に 詨し，特閏的にどのよらな変化を起こし得るかなよ゙に ついてまず乎術用ゴム手袋をマク口的に観察するべく， 電気的計測を行った。ささにとの結果を考察し，いく つかの新知見を得たので報告する。 